\title{
Critical thinking and creative pedagogies in the classroom
}

Pensamento crítico e pedagogia criativa na sala de aula

\section{각}

Fernando Naiditch ${ }^{1}$

Bettina Steren dos Santos ${ }^{2}$

\begin{abstract}
The article discusses the meanings and the roles of critical thinking in the classroom. We start by placing the concept within the progressive pedagogical movement, which is rooted in the idea of learning by doing. Experiential learning is at the core of this kind of pedagogy and the belief is that students can only truly learn by engaging with the curriculum in an active and meaningful manner. Developing critical thinking is the goal of any educational system, particularly in democratic nations that understand schooling as a way of socializing children into the life of society as productive citizens. Although there seems to be an agreement in the importance of critical thinking in schools, teachers still find it difficult to develop practical classroom lessons and instructional strategies that develop higher order thinking skills. We discuss inquiry and project-based learning as well as Freire's problem-posing approach as pedagogical instructional tools that can be used in the classroom to help students develop critical thinking.
\end{abstract}

${ }^{1}$ Doutor em Educação Multilíngue e Multicultural pela New York University (NYU) - United States. Mestrado em Aquisição da Linguagem na Universidade Federal do Rio Grande do Sul (UFRGS)-Brasil. Professor na Montclair State University - United States What do you want to do.

${ }^{2}$ Professora Visitante na Universidade de Barcelona. Pós-doutorado em Educação pela Univeristy of Texas at Austin (UT) - United States. Doutora em Psicologia Evolutiva e da Educação pela Universidade de Barcelona (UB) - Espanha. Trabalha na Pontificia Universidade Católica do Rio Grande do Sul (PUCRS) - Brasil.

Interfaces da Educ., Paranaíba, v.11, n.32, p. 711 - 734, 2020 
Key words: Critical thinking. Active pedagogies. Inquiry-based learning. Project-based learning. Problem-posing method.

\section{Resumo}

$\mathrm{O}$ artigo discute os significados e os papéis do pensamento crítico na sala de aula. Começamos colocando o conceito dentro do movimento pedagógico progressivo, que está enraizado na ideia de aprender fazendo. A aprendizagem experiencial é o cerne desse tipo de pedagogia e a crença é que os estudantes só podem aprender verdadeiramente se estiverem envolvidos com o currículo de forma ativa e significativa. Desenvolver o pensamento crítico é o objetivo de qualquer sistema educacional, particularmente nas nações democráticas que entendem a escolaridade como uma maneira de socializar as crianças na vida da sociedade como cidadãos produtivos. Embora pareça haver um acordo sobre a importância do pensamento crítico nas escolas, os professores ainda acham dificil desenvolver aulas práticas em sala de aula e estratégias instrucionais que desenvolvam habilidades de pensamento de ordem superior. Discutimos o aprender pela pesquisa e a aprendizagem baseada em projetos, bem como a abordagem de levantamento de problemas de Freire como ferramentas pedagógicas que podem ser usadas na sala de aula para ajudar os alunos a desenvolver um pensamento crítico.

Palavras chaves: Pensamento crítico. Pedagogias ativas. Aprendizagem pela pesquisa. Aprendizagem baseado em problemas. Problematização

\section{Introduction}

Critical thinking today is at the core of every discussion surrounding progressive and active pedagogies. The idea of having learners engage with content and material in a critical, thoughtful, and inquisitive manner has become widely accepted and is considered a goal for every classroom in every grade level and content area. Since John Dewey (1938) aptly described what Interfaces da Educ., Paranaiba, v.11, n.32, p. 711 - 734, 2020 
experiential learning looks like through his Laboratory School, educators involved in progressive pedagogies have been developing instructional $\boldsymbol{m}$ approaches that not only value experience over learning facts, but also prioritize understanding by doing over learning by memorizing.

Teaching students how to think, though, is not an easy task. Traditional pedagogical approaches that value rote learning and memorization have historically been associated with notions such as intelligence and knowledge (HIRSCH, 2016). Students who were able to store large pieces of information and retrieve them by regurgitating material learned back to their teachers were routinely considered the smart students in the room. These students did in fact have an important ability. Memory is part of learning and it does play a role in the schooling process (BERAN, 2004). However, the long-established belief that learning was mostly about storing and retrieving facts and information has been replaced by the idea that learning is about relating to and using information in novel and creative ways (LITTLE AND ELLISON, 2015).

Access to technology has played a huge role in that change (COLLINS AND HALVERSON, 2018). As new generations of students belong to the world of digital natives and as more technological advances bring knowledge to our hands by just touching a screen, there is no way of denying that looking for information, accessing facts and getting answers to our questions have become easier and mundane tasks. Technology has shrunk the world. As a result, our ways of learning have changed dramatically - and so have our ways of teaching.

The challenges that have come with the new approaches and ways of understanding teaching and learning are basically related to how we teach someone to think critically. Within traditional educational approaches that focused on facts and information, the teachers' role was basically to introduce the information that had already been selected and edited for the students. Now, however, students are basically saturated with information and facts, and the problem that they face is how to distinguish fact from fiction, how to identify reliable sources, and how to sort through so much information. For Interfaces da Educ., Paranaíba, v.11, n.32, p. 711 - 734, 2020 
teachers, the challenge is how to teach them to do these things by guiding them through the development of critical thinking skills.

Progressive education usually addresses this question by highlighting the assets of active and engaging pedagogical approaches where students learn by doing. Experiential education requires students to be on task in instruction that is hands-on, inquiry and project based.

\section{A Closer Look at Critical Thinking}

Critical thinking is one of those broad concepts which spans over various disciplines and is studied under different approaches. Historically, critical thinking is a philosophical concept (BATTERSBY, 1989), which makes it not only a theoretical concept, but also one that derives from formal logic. As a cognitive skill, critical thinking has also been largely studied in the field of psychology. A good number of psychometric tests which aim at measuring a person's mental capabilities and behavioral styles have delved into critical thinking and the possibility of measuring one's ability to think critically and to develop this cognitive skill.

When Dewey (1910) referred to the term critical thinking, he described it as an educational goal and associated it with a scientific attitude of the mind. This understanding reflected Dewey's recognition of the curious and inquisitive minds of children as well as their ability to engage in experimental inquiry. These ideas were later put to practice as pedagogical approaches in his Laboratory School in Chicago where students' scientific attitudes were encouraged by building on their natural curiosity, imagination, and disposition for experimentation.

In 1933, when he rewrote How We Think (originally published in 1910), Dewey emphasized the critical nature of this type of thinking by referring to it as reflective thinking. In his own words, critical thinking "calls for a persistent effort to examine any belief or supposed form of knowledge in the light of the 
evidence that supports it and the further conclusions to which it tends" (DEWEY, 1933, p. 9).

The idea of critical thinking being reflective is recurrent in the definitions of the concept, which means that engaging in this kind of thinking requires students to be flexible, adjustable as well as having an open mind and an unbiased attitude.

Baron $(1994,1996)$ builds his concept of critical thinking on this need for thinkers to keep an open mind by using the notion of actively open-minded thinking.' For him, critical thinking is developed when students are faced with a situation or a problem that needs solutions. In order to come up with responses to the situation being presented, students need to search for alternatives sufficiently and thoroughly - all possibilities need to be considered. Baron goes on to say that critical thinking is 'good thinking' when it involves searching for alternative perspectives other than the initial or the preferred one, integrating across these perspectives, and making appropriate and necessary adjustments to get to an acceptable conclusion (BARON, 1996). This definition sees critical thinking as an ability to search and locate possible answers to a problem, analyze the impact and consequences of the answers found in order to generate a conclusion or a result. Critical thinking, in this sense, is a process of identifying alternatives, sorting through possibilities, and selecting the ones that can have effective outcomes.

Ennis (1995) is another researcher who has studied critical thinking and defined it as reasonable, reflective thinking that is aimed at deciding what to believe and what to do. Ennis' definition provides a balance between belief and action that is shaped as a decision-making process. Many times, we are presented with matter-of-fact situations whose decisions are solely based on facts. For example, the decision on whether to bring an umbrella with us is based on weather conditions. On other situations, however, our decisions are more abstract or personal. For example, deciding the best restaurant to go for dinner with the family involves evaluation, and different families may come up Interfaces da Educ., Paranaiba, v.11, n.32, p. 711 - 734, 2020 
with different responses based on their characteristics and preferences. Ennis' definition of critical thinking reminds us that any decision-making process is based on facts, but that there is also an assessment of variables that affect outcomes. We all need to make daily life decisions based on facts and an evaluation system. Critical thinking helps students develop their beliefs by analyzing facts. We learn to make choices based on what is real and can be measured and studied, but also considering that we are individuals and that our choices and beliefs are also based on our experiences, values, and lifestyles. Simply put, critical thinking is a goal-oriented process. Once we identify our goal, we need to make decisions about the best way or ways to achieve it.

Hunter (2014) builds on Ennis' definition of critical thinking as a decision-making process and points out that decisions are not random or arbitrary. He delves into Ennis' idea of reasonable and reflective thinking by asserting that critical thinking needs to be "reasonable thinking because it is governed by general methods and standards and because it demands we have good reasons for our decisions" (HUNTER, 2014, p. 4). Moreover, critical thinking needs to be reflective "because it involves thinking about a problem at several different levels or from several different angles all at once, and because it sometimes requires thinking about what the right method is to answer or solve some problem" (HUNTER, 2014, p. 4).

This emphasis on reason and reflection mirrors Baron's idea of 'good thinking,' after all critical thinking is not just about deciding, but also giving good reasons for the decision taken by providing a rationale or justification. Critical thinking, therefore, has a method for developing arguments that provide logical support to our choices and decisions.

This is not to say that critical thinking is an exact science. There is a reason we associate it with creative thinking in this article, which is because there is room for flexibility and judgment. A critical thinker needs to be creative 
in coming up with alternatives and flexible while analyzing them to consider contextual variables.

For example, in mathematics, when students are solving problems that require calculation, the teacher requires a 'correct' or 'right' answer. Students engage in different kinds of thinking while calculating and analyzing a problem, but there is usually an expected answer - a number, a numeral, or a numeric value. This example demonstrates that there are many situations in life where our answers are straightforward.

However, there are many other situations where our solutions are not that simple and that require further consideration. These are open-ended problems which require the kinds of solution or answers that are not always easily achieved. We do not necessarily know what courses of action to take or what the solution will be. Therefore, critical thinking is about having an open and inquisitive mind. While searching for answers or solutions, we need to look at a problem from different angles, conflicting perspectives, and consider various viewpoints. This is why the role of argumentation and reasoning are central to any task that requires critical thinking.

In its landmark 1990 Delphi Report (which was revised in 1998), the American Philosophical Association (APA) defined critical thinking as "the process of purposeful, self-regulatory judgement. This process gives reasoned consideration to evidence, context, conceptualizations, methods, and criteria" (FACIONE, 1990, p. 2). Based on the APA Expert Consensus Delphi Report, strong critical thinkers demonstrate the following characteristics, as stated in Insight Assessment, 2020:

- inquisitiveness with regard to a wide range of issues

- concern to become and remain well-informed

- attentive to opportunities to use critical thinking

- self-confidence in one's own abilities to reason

- open-mindedness regarding divergent world views

- flexibility in considering alternatives and opinions 
- alertness to likely future events in order to anticipate their consequences

- understanding of the opinions of other people

- fair-mindedness in appraising reasoning

- honesty in facing one's own biases, prejudices, stereotypes, or egocentric tendencies

- prudence in suspending, making or altering judgments

- willingness to reconsider and revise views where honest reflection suggests that change is warranted

As we can see from the definitions and descriptions above, critical thinking is about making informed decisions, well-founded judgements, and substantiated claims. It has been an essential aspect of the educational system for its role in forming informed and critical citizens and its importance in establishing and sustaining democratic and free societies. The use of critical thinking in the curriculum has not always been emphasized or strengthened, and it depended on the type of pedagogical approach being used at the moment. In the eighties, critical thinking became once again a hot topic in education (NICHOLAS and RAIDER-ROTH, 2016), prompting teachers and teacher educators to start looking at ways curriculum and instruction could address it as a pedagogical practice.

Critical thinking from a pedagogical perspective requires educators to understand classrooms as spaces of knowledge production and not knowledge reproduction. Students, as suggested by Freire (1970), need to become subjects of their histories with an active role in the meaning-making process that transforms the classroom.

Critical thinking is a skill that needs to be practiced and developed. Students do not learn to think critically unless they are taught to do so. Students need to be exposed to and engage in pedagogical practices that require them to connect to what they know and do, to make meanings and consider possibilities, and to come up with creative and innovative solutions to problems. 
Critical thinking is often understood as a primary skill under which we find a subset of skills, or subskills, such as assessing, reasoning, analyzing, interpreting, decision making, problem solving, among others. In order to perform all these subskills, students need to learn to think creatively and critically about the situations at hand and the ways which a problem or an issue can be approached, tackled, and/or solved.

Willingham (2007) has argued that critical thinking requires access to content knowledge because the processes used in thinking are implicitly associated with the content of thought. This means that in order to develop critical thinking, one needs to have developed content first and be able to access this knowledge when engaged in the process of thinking.

In this sense, critical thinking is a process of connection - connecting information to its application. Naiditch (2017) describes critical thinking as applied knowledge (as opposed to dormant knowledge). In his view, when students learn information in schools just for the sake of memorization, they will eventually forget what they have learned. They are certainly developing and broadening their knowledge of the world, but unless the information learned is going to be used for future action, students will most likely store it for a certain period of time and will end up dismissing it from their minds. New information will be stored, and this cyclical process will continue until students are actually asked to retrieve the information they stored for practical purposes.

Critical thinking, therefore, is about applied knowledge; an ability to retrieve and use information to change a problem or a situation. Critical thinking implies looking at an issue in original and creative ways and students can only do so when they are able to choose between the different sub-skills involved in critical thinking to make meaningful connections between facts to arrive at a novel solution, idea or explanation (NAIDITCH, 2017).

Our students are growing in a world where information is produced and transmitted at the speed of light. There is more information available than one can actually process and understand. Being able to differentiate and Interfaces da Educ., Paranaíba, v.11, n.32, p. 711 - 734, 2020 
discriminate between different pieces of information is vital for survival in a world of fake news and intense social media influence where new tools and means of communication are being developed extraordinarily fast, constantly, and purposefully. This is another reason why critical thinking is crucial in education for life, after all, as Naiditch (2013) has said, the goal of critical thinking is to "enable people to live their lives as informed, critical and actively engaged citizens of their communities and society and to also develop a sense of responsibility towards themselves and others" (NAIDITCH, 2013, p.340).

\section{Instructional Approaches to Developing Critical and Creative Thinking}

Thinking critically and creatively requires looking at a question, an issue, a problem, or a situation with fresh eyes and using a novel perspective in dealing with it. This is why people usually refer to this kind of thinking as 'thinking outside the box'. The expression reflects well the idea of coming up with unconventional or unorthodox ways of tackling an issue. Creativity drives innovation, and in order to advance a society, its members need to be critical in understanding its problems and creative in offering solutions.

In order to understand the use of critical thinking as a pedagogical tool and as an educational aim in the classroom, it is important to contextualize it and understand its association with progressive education.

The progressive education movement started to flourish at the end of the $19^{\text {th }}$ century as a reaction to more formal and traditional kinds of education. Traditional schooling centers around the presence of a teacher who makes all the instructional, pedagogical, and administrative decisions in the classroom. In this teacher-centered form of instruction, the focus of the class is on content, i.e. what it taught, and students are mere spectators who are there to receive information passively without necessarily engaging with the content being taught.

Progressive education also focuses on what is taught - content - but emphasizes how it is taught, i.e., the variety of instructional strategies, Interfaces da Educ., Paranaiba, v.11, n.32, p. 711 - 734, 2020 
classroom configurations, types of interaction and grouping, materials and resources that will engage students actively with the content and promote different ways of learning and relating to the content and materials at hand.

John Dewey and Francis Parker are known as the proponents of progressive education in the United States. Their dissatisfaction with traditional forms of schooling was based on the prescriptive nature of traditional education and the narrow curriculum that it embodies. Traditional education is seen as reproductive because it basically focuses on enculturating children into what is considered the official knowledge of a society. This official knowledge represents the values and aspirations of an intellectual and economic elite who basically dictates what everyone needs to know and learn in schools (APPLE, 2014).

The progressive education movement challenged this traditional idea of classroom and curriculum by engaging children in questioning existing knowledge and producing new knowledge. The idea of students taking ownership of their own learning process by engaging in an inquiry-based pedagogy builds on the natural curiosity and interests that children have and bring to school. In progressive classrooms, the teacher is not at the center of instruction, and teaching and learning become student-centered, driven and directed endeavors.

Dewey's central idea of the role of experience in the teaching and learning processes are encouraged through a pedagogy that stimulates and values exploration and discovery, inquiry and engagement. It is ultimately a continuous process of reconstructing experience.

In his testimony to the Progressive Education Network, Jon Kidder (2020, on-line) managed to summarize the essence of a progressive approach to education while describing the work developed at the Park Day School in California:

Our academic program is driven by our enduring respect for children as thinkers and explorers, curious scientists and mathematicians, imaginative writers and artists, and as makers of change in the interest 
of equity and justice: children who possess important ideas and theories about their world.(on-line)

It is within this perspective that the idea of critical thinking is strongly encouraged and emphasized. In progressive classrooms, students are taught how to think critically as they develop hands-on projects, solve problems, and become lifelong learners.

Critical and creative thinkers also need to develop social skills that have been described as essential in advancing a society (GLADWELL, 2019). One such skill is the ability to work in collaborative environments. People who know how to develop teamwork are more likely to come up with solutions that complement and extend one another. The ability to work in teams allows us to deal with diverse groups of people who work together to create meaningful associations. This joint effort results in a partnership where participation requires taking advantage of everyone's best ideas, learning styles, and ways of relating and communicating (PAGE, 2007).

Teamwork is also the result of individual achievement and reflects the independent work that each contributor has put in developing his or her own thinking. Groups produce better results than sole individuals, but groups only function properly if these individuals can negotiate ways of building from each other's contributions.

Another element of progressive pedagogy comes from a philanthropist, Edward Harkness, whose idea of students sitting at a round table with a teacher who would talk to them in a tutorial manner gave way to what is known as the Harkness Method. This is a way of thinking of classroom space where the teacher is no longer positioned in front of the class, but instead interacts with the students as a facilitator. The Harkness Method became very popular within progressive education circles because it positions the teacher differently in order to minimize his or her intervention and maximize students' ownership of their learning. By focusing on discussion, the Harkness Method also reminds us that class time needs to be spent with students engaged in conversation and Interfaces da Educ., Paranaíba, v.11, n.32, p. 711 - 734, 2020 
dialogue where they will have opportunities to develop important skills related to critical thinking, such as exchanging ideas, agreeing and disagreeing, $\boldsymbol{m}$ developing arguments, making a case, examining evidence, comparing and $\mathbf{N}$ contrasting information, among others.

Establishing an environment that is conducive to the development of critical thinking skills is an essential aspect of a progressive classroom that aims at empowering students and providing them with the tools they need to succeed academically and in life. Classroom space needs to be reorganized so that students can truly interact with one another and engage in dialogical action (FREIRE, 1970). The idea of a classroom organized in rows and columns is associated with traditional education, which prevented students from interacting or even facing one another. Classroom space that promotes dialogue, interaction, and collaboration needs to be thought of as a space for groups, circles of learning and free of unnecessary barriers. The idea of flexible seating, which has been spreading across schools in the United States, has helped teachers, students, and administrators rethink spaces of learning to maximize learning opportunities, promote student well-being, intensify classroom interaction and, ultimately, strengthen teaching and learning.

Flexible seating refers both to the choice students have when choosing the area they would like to work in the classroom as well as the kind of seating arrangements and objects used for seating. Some classrooms have even abandoned the traditional chairs and desks to make room for tables that can be moved easily and for seat alternatives such as stools, bean bags, balance ball chairs or even the floor. Hare and Dillon (2016) defend the idea of students becoming co-designers of the classroom space. Because students spend so much time in that environment, they should have an opportunity to make decisions about their health, level of comfort, and ability to move around that space. Spaces that can be changed mirror the world outside the classroom and allow for different kinds of interaction and engagement. 
Hare and Dillon (2016) discuss one fundamental question that teachers need to ask themselves: Do our learning spaces still serve our students? It is not just the pedagogy that needs to be changed to accompany the changes in the world, advances in technology, and in the ways, we understand knowledge. Classroom space and time also directly affect our students and will influence the kinds of teaching and learning that take place in the room.

Critical thinking requires rethinking teachers 'and students' roles as well classroom space and time. Instructional strategies that promote critical thinking will need to take advantage of the space and the time allotted to amplify learning opportunities. As teachers and students navigate learning spaces and use their time engaged in activities that develop critical thinking skills, they take on new roles. The teacher becomes a facilitator who supports learning by offering guidance and providing the necessary scaffolding. Students take ownership of their learning and become empowered by having some degree of choice. This does not mean that all decisions are in the hands of the students, but that once the teacher presents the work to be done, there will be opportunities for students to choose how to approach the task. Choice is a key element in this kind of progressive teaching. When students are given choices, they are developing critical thinking skills by learning to make decisions. The world is full of choices and we, as educators, cannot make all the choices for our students. If students are expected to learn to make appropriate choices for themselves, the classroom should be the space where they learn to solve problems and make decisions independently.

The kinds of pedagogy, including the tasks and activities that students engage with, will dictate the kinds of skills or sub-skills they will be developing. Generally speaking, progressive educators tend to agree that inquiry and project-based learning are instructional strategies that lead students to develop critical thinking skills because they require learners to actively study a particular problem in depth by asking questions, searching for answers, testing and experimenting until they get to a conclusion (PEDASTE et. al., 2015). Interfaces da Educ., Paranaíba, v.11, n.32, p. 711 - 734, 2020 
Moreover, inquiry and project-based learning are self-directed and help learners develop a sense of responsibility as well as a voice since it is up to them to $\boldsymbol{\Omega}$ create knowledge based on what they discover during the learning process (WILHELM; BEISHUIZEN, 2003; STACEY, 2018; MACKENZIE, 2019).

Both inquiry and project-based learning start with a question that is posed to the students, a problem that needs to be solved or a challenge that needs to be addressed. In order to develop the inquiry or the project, students will need to learn about the facts, ask additional questions, research, and decide on courses of actions. Inquiry and project-based learning are about learning through discovery; students will need to engage in a series of steps to uncover the nature of the issue they are studying, to make meaning and to get to their conclusions. Whether the teacher refers to the pedagogical strategy as

inquiry or project-based learning, the only difference is that inquiry-based learning is about discovering an answer, whereas project-based learning focuses on exploring an answer (BOSS; LARMER, 2018; ROSS MURPHY, 2017).

\section{Critical Thinking in the Classroom}

Because of its vast use and broad range, critical thinking is not a content-based or discipline-specific concept. Different fields of knowledge have studied and developed critical thinking practices that address the specific characteristics of that field. What they seem to have in common, particularly within the so-called academic discourse, is that the focus is on reasoning and argumentation. The ability to engage in the academic discourse within a certain field and understand its logic while also being able to develop ideas that are sound, coherent, and evidence-based seem to be at the center of the skill of critical thinking.

In schools, it is common to see teachers across grade levels and content areas addressing and teaching critical thinking skills at all levels by encouraging students to ask relevant questions, learn to search for appropriate answers, and develop meaningful connections between ideas.

Interfaces da Educ., Paranaiba, v.11, n.32, p. 711 - 734, 2020 
Critical thinking skills are always included in the larger educational conversation about what is referred to as $21^{\text {st }}$ century learning skills. These are skills that have been identified as essential for a person to function in the modern society. In the United States, there is even a movement referred to as ' $21^{\text {st }}$ Century Skills,' which aims at identifying what skills are necessary for students to succeed academically, in their future workplace, and as citizens of a larger society. The premise is that the world has changed and that the skills that were being taught in schools in the past no longer serve the purposes and the needs of the current world. Schools need to reflect these changes in society and prepare students for the challenges of the $21^{\text {st }}$ century.

The National Education Association (NEA) created the Partnership for $21^{\text {st }}$ Century Skills (P21) which aimed at identifying the skills that were most important for educators and schools to focus on as they prepare students and citizens for the new century. As a result of this effort, the NEA came up with the "Four Cs," a list comprised of the four basic skills deemed essential for $21^{\text {st }}$ century living:

- Critical thinking

- Communication

- Collaboration, and

- Creativity

Critical thinking tops the list, and this is no surprise. As we mentioned before, the vast amounts of information that are readily available in today's world makes it necessary for people to learn to compare and contrast facts and evidence, evaluate claims and make appropriate decisions. In addition, in order to solve global problems, such as poverty, disease, and climate change, we need critical thinkers with problem-solving skills, and the ability to select, interpret, analyze, and synthesize data to discover and produce creative and innovative solutions. 
The Partnership for $21^{\text {st }}$ Century Skills identifies four basic elements of critical thinking that educators should develop in their classes. In schools, students should learn to:

a. Reason effectively

b. Use systems thinking

c. Make judgements and decisions

d. Solve problems

The challenge remains how to develop lessons that truly help students engage in critical thinking and develop higher order thinking skills. In his analysis of the use of critical thinking in science teaching, Balcaen (2011) identifies a number of intellectual tools that help educators embed critical thinking into their pedagogical practice. His model of teaching thoughtfulness includes:

1. Providing a specific form of challenging questions;

2. Teaching the required intellectual tools;

3. Assessing the intellectual; and

4. Supporting the development of both virtual and face-to-face communities of critical thinkers.

The first component for teaching critical thinking requires teachers to ask complex questions in the classroom. Asking questions is in fact one of the most difficult tasks that teachers should learn. Because of time constraints, it is very common to see teachers resorting to yes/no questions or even to rhetorical questions when they do not even give students enough time to process what has been asked. Learning to formulate and ask question that require deep thinking and complex relationships will engage students more intricately with the content and the curriculum.

The second component identified by Balcaen (2011) is the explicit teaching of the tools for thought. Students need to be taught how to think by having the teacher model thinking out loud. The interesting aspect of teaching tools of thought is that students learn to 'think out-loud,' i.e., as they engage in Interfaces da Educ., Paranaiba, v.11, n.32, p. 711 - 734, 2020 
a task, they need to explicitly say, write or describe the steps they are taking to approach or solve that task. This also requires the development of metacognitive tools. By thinking out loud students engage in a metacognitive process of verbalizing their understanding by identifying how they are approaching a task and how their thinking is evolving. This also makes students aware of the cognitive skills needed to deal with different tasks and learning problems.

While developing these tools, students will necessarily resort to:

a. Background knowledge

b. Criteria for judgment

c. Critical thinking vocabulary

d. Thinking strategies, and

e. Habits of the mind

The third component involves assessing students' competence in using the intellectual tools as they develop their responses and engage in the tasks and activities. This assessment needs to be done regularly and systematically. Teachers need to develop clear criteria and achievable standards. This is usually done by creating a rubric. Scoring rubrics are used to assess the quality of students' answers or responses. They also serve as a way for the teacher to communicate the expectations in terms of the quality for a task. Assessment can also involve students' input and teachers can use self and peer assessment as ways to engage students in their own assessment.

The final component in Balcaen's model is building critically thoughtful communities. These are basically communities of thinkers that will extend the work developed in the classroom in both face-to-face and virtual interactions and will find and develop additional opportunities to practice critical thinking skills. For these communities to extend beyond the classroom, teachers need to pose questions regularly and design challenging assignments that provide ongoing opportunities for students to engage in critical and cooperative dialogue. Students develop collaborative thinking by discussing, explaining, Interfaces da Educ., Paranaíba, v.11, n.32, p. 711 - 734, 2020 
demonstrating, arguing. Critically thoughtful thinkers engage in communicative interactions and dialogical action that promote extended opportunities for them to express their views, learn from others, and create new frames of reference.

The idea of developing critical thinking through dialogical action inevitably leads us to Freire's (1970) problem-posing approach to education. Problem-posing pedagogy starts with the work of Dewey and Piaget whose emphasis on experiential education, learners' active participation, and the development of an inquiry mindset in the classroom promoted student-centered curriculum that helped students create knowledge instead of memorizing facts.

Freire (1970) positions the teacher as a problem-poser whose responsibility is to:

Diversify subject matter and to use students' thought and speech as the base for developing critical understanding of personal experience, unequal conditions in society, and existing knowledge. In this democratic pedagogy, the teacher is not filling empty minds with official or unofficial knowledge but is posing knowledge in any form as a problem for mutual inquiry" (FREIRE, 1970 apud SHOR, 1992, p. 3233).

The students become critical co-investigators" who engage "in dialogue with the teacher" (FREIRE, 1970, p. 68) and with the material at hand (NAIDITCH, 2010). Within the problem-posing pedagogy, critical thinking is developed by first identifying a problem that usually comes from the students. Once the group decides on the problem they will investigate, they develop a broader understanding of the issues involved and engage in a meaning making process where they make relationships between the problem and other issues, analyze reasons and consequences to finally come up with possible solutions and ways of addressing the problem identified.

Auerbach (1990) describes five steps learners go through within the problem-posing approach:

1. Describe the content: the content comes from what is referred to as a code. A code originates from learners' experiences and reflect the problem being studied.

Interfaces da Educ., Paranaíba, v.11, n.32, p. 711 - 734, 2020 
2. Define the Problem: students uncover the issue presented in the code.

3. Personalize the problem: students relate the problem to their lives, cultures, and experiences,

4. Discuss the problem: students engage in a contextualized discussion. They analyze different aspects of the problem and how it affects them individually and as a community.

5. Discuss alternatives to the problem: students propose ways of dealing with the problem. They suggest different ways of addressing the problem and weigh the possible consequences of alternatives created.

By following Auerbach's five-step model, students select and make the problem meaningful to their context and the larger community. Teachers facilitate this process by guiding students through these steps with questions that engage them and that make them consider different perspectives.

Whether a teacher follows a problem-posing approach, inquiry or problem-based learning, students should spend instructional time in activities and tasks that challenge them to think deeply and that encourages them to develop a subset of critical thinking skills, such as predicting, inferring, comparing, contrasting, relating, reflecting, analyzing, and synthesizing (SANTOS; SPAGNOLO; BUCKER, 2018). It is the systematic practice of these subskills that will help students to develop the kind of creative and critical thinking they need to succeed in life.

\section{Final Thoughts}

As we described critical thinking in this article, we also called for the use of creative pedagogies that would promote and enhance the development of higher order thinking skills in the classroom. Teaching students to analyze facts, so they can get to an informed conclusion, decision or judgement is a complex process that needs to be carefully planned, intentionally implemented, and extensively practiced in schools. 
In order to teach students to think critically, educators also need to consider its multilayered nature. We have argued that critical thinking is a major skill that can be tackled pedagogically through the teaching of its subset of skills. Because critical thinking is a complex kind of thinking, breaking it down into subskills may help teachers guide students as they learn to formulate their thoughts, develop their arguments, and justify their choices and opinions.

Students come to school with a variety of learning styles and different ways of thinking and doing based on their background knowledge and previous experiences. As they encounter new experiences at school, students learn to identify their needs and build upon their strengths.

Dewey believed that education had to be based on experiences and that students would progress by building upon these experiences which would lead to the creation of yet new experiences. Education needs to be experiential, practical and provide students with the tools they need to develop their thinking. Because it is a meaning-making process, critical thinking is at the center of any educational approach that aims at forming informed and conscientious citizens in a democratic society.

As students learn new information, and as they are confronted with new and diverse content, they need to learn to interpret and respond to what they are being presented. As students learn new things in school, they also need to learn to react and respond to what they learn, and they can only do that if they can relate to the materials and content in a critical way. Critical thinkers are competent thinkers. They achieve academically and socially, and they are fully prepared to engage in the life of a global society.

If schools genuinely want to invest in the kind of teaching that will give all students equal opportunities to succeed, making use of creative pedagogies will not only engage diverse students in more meaningful learning experiences, but will also promote more reflective, independent, and critical thinking. 


\section{References}

AUERBACH, ELSA. Making meaning, making change: A guide to participatory curriculum

development for adult ESL and family literacy. Boston: University of Massachusetts, 1990.

BALCAEN, PHILIP L. The Pedagogy of Critical Thinking: Object Design Implications for Improving Students' Thoughtful Engagement Within E-learning Environment. US-China Education Review, B3, p. 354-363, 2011.

BATTERSBY, MARK. Critical Thinking as Applied Epistemology: Relocating Critical Thinking in the Philosophical Landscape. Informal Logic, XI, 2, p. 91100, 1989. From: file:///C:/Users/bsantos/Downloads/2623-Article\%20Text-46621-10-20090812.pdf. Retrieved October 12, 2019.

BERAN, MICHAEL KNOX. In Defense of Memorization, 2004. From: https://www.city-journal.org/html/defense-memorization-12803.html.

Retrieved October 10, 2019.

BOSS; SUZIE; LARMER; JOHN. Project Based Teaching: How to Create Rigorous and Engaging Learning Experiences. Alexandria, VA: ASCD, 2018.

COLLINS, ALLAN and HALVERSON, RICHARD. Rethinking Education in the Age of Technology: The Digital Revolution and Schooling in America. New York: Teachers College Press, 2018.

DEWEY, JOHN. How We Think. Boston: D.C. Heath, 1910.

. How We Think: A Restatement of the Relation of Reflective Thinking to the Educative Process. Lexington, MA: D.C. Heath, 1933.

. Experience and Education. New York: Kapa Delta Pi, 1938.

FREIRE, PAULO. Pedagogy of the oppressed. New York, NY: Continuum International Publishing Group, 1970.

GLADWELL, MALCOLM. Talking to Strangers: What We Should Know About the People We Don’t Know. New York, NY: Little, Brown and Company, 2019.

HARE, REBECCA LOUISE; DILLON, ROBERT. The Space: A Guide for Educators. Irvine, CA: EdTechTeam Press, 2016.

HIRSCH. E. D. Jr. Why Knowledge Matters: Rescuing Our Children from Failed Educational Theories. Cambridge, MA: Harvard Education Press, 2016. 
INSIGHT ASSESSMENT. Characteristics of Strong Critical Thinkers. From: https://www.insightassessment.com/article/characteristics-of-strong-criticalthinkers. Retrieved April 23, 2020.

JONATHAN BARON. Thinking and deciding (2nd edition). New York: Cambridge $\mathbf{N}$ University Press, 1994. . Actively open-minded thinking. Almanac, Volume 42, Number 24, 1996.

KIDDER, Jon. Testimony on Progressive Education. From: https://progressiveeducationnetwork.org/. Retrieved April 21, 2020.

LITTLE, TOM; ELLISON, KATHERINE. How Progressive Education Can Save America's Schools. New York: W. W. Norton \& Company, 2015.

MACKENZIE, TREVOR. Dive into Inquiry: Amplify Learning and Empower Student Voice. Victoria, BC: Elevate Books Edu, 2019.

MICHAEL W. APPLE. Official Knowledge (3 ${ }^{\text {rd }}$ edition). New York: Routledge, 2014.

NAIDITCH, FERNANDO. (Ed.). Developing critical thinking: From theory to classroom practice. Lanham, MD: Rowman \& Littlefield, 2017.

. A media literate approach to diversity education. Journal of Media Literacy Education, 5(1), 337-348. 2013.

Critical pedagogy and the teaching of reading for social action. Critical Questions in Education, 1(2), 94-107, 2010.

NICHOLAS, MARK C.; RAIDER-ROTH, MIRIAM. A Hopeful Pedagogy to Critical Thinking. International Journal for the Scholarship of Teaching and Learning, 10 (2), p. 1-10, 2016.

PAGE, SCOTT E. The Difference: How the Power of Diversity Creates Better Groups, Firms, Schools, and Societies. Princeton, NJ: Princeton University Press. 2007

PEDASTE, MARGUS et. al. Phases of inquiry-based learning: Definitions and the inquiry cycle. Educational Research Review, vol. 14, pp. 47-61, 2015. From https://doi.org/10.1016/j.edurev.2015.02.003. Retrieved October 10, 2019.

PETER A. FACIONE. Critical Thinking: A Statement of Expert Consensus for Purposes of Educational Assessment and Instruction - The Delphi Report. Insight Assessment. California Academic Press, 1998. 
ROBERT H. ENNIS. Critical Thinking. Upper Saddle River, NJ: Prentice Hall, 1995.

SANTOS, B. S.; SPAGNOLO, C.; BUCKER, C. Creativity and Motivation in the Teaching and Learning Process. In: Fernando Naiditch. (Org.). Developing Critical Thinking: From Theory to Classroom Practice. 1ed.Lanham, Maryland: Rowman \& Littlefield, 2016, v. 1, p. 1-175.

SHOR, IRA. Empowering Education: Critical Teaching for Social Change. Chicago: University of Chicago Press, 1992.

STACEY, SUSAN. Inquiry-Based Early Learning Environments: Creating, Supporting, and Collaborating. St. Paul, MN: Redleaf Press. 2018.

WILHELM; P.; BEISHUIZEN; J. J. Content effects in self-directed inductive learning. Learning and Instruction, vol. 13, p. 381-402, 2003.

WILLINGHAM, DANIEL T. Critical thinking: Why is it so hard to teach? American Educator, summer issue, 8-19, 2007. 